\title{
THE GROUNDS AND MORE SERIOUS FORMS OF DISCRIMINATION IN CROATIA
}

Sanja Bježančević, mag. oec.*

\author{
UDK 347.722(497.5) \\ $341.231 .14(497.5)$ \\ https://doi.org/10.30925/zpfsr.42.1.2 \\ Ur.: 8. rujna 2020. \\ Pr.: 31. listopada 2020. \\ Izvorni znanstveni rad
}

\begin{abstract}
Summary
Although the legislative framework for protection against discrimination in Croatia covers a considerable number of grounds and could be described as satisfactory, discrimination in society is present to a greater extent than that registered in complaints received by the Office of the Ombudswoman. Different treatment of a person or persons may involve several different legally protected grounds, resulting in a more serious form of discrimination defined under the Anti-Discrimination Act as multiple discrimination. The concept of multiple discrimination is very complex and multi-layered. Thus, the focus of this research was to conduct a survey on 761 respondents stratified by sex, education, and age. The chi-square test examined the relationship between the grounds of discrimination provided by respondents who declare themselves victims of discrimination in the area of work and working conditions, in the area of education and justice, and based on their sex, level of education, and age. The results of the research show that more than half of the respondents experienced some form of discrimination and that more than half of the respondents who declare themselves victims of discrimination experienced some of the more serious forms of discrimination.
\end{abstract}

Keywords: discrimination; grounds of discrimination; areas of discrimination; multiple discrimination; European Union.

\section{INTRODUCTION}

The preconditions for the realization of equal opportunities and the regulation of protection against discrimination in the Republic of Croatia are ensured by the Anti-Discrimination Act. Although the legislative framework for protection against discrimination covers a considerable number of grounds and could be described as satisfactory in terms of protection mechanisms, discrimination in society is present

* Sanja Bježančević, mag. oec, Agricultural Institute Osijek; sanja.bjezancevic@gmail.com; ORCID: https://orcid.org/0000-0002-5253-2581. 
to a greater extent than that registered in the complaints received by the Office of the Ombudswoman. There are various reasons as to why victims of discrimination opt for non-action, but one of the fundamental ones is probably insufficient information and education about the harmfulness of this problem. This is the direction that should guide the formulation of preventive measures and national policies, the aim of which should be empowering victims of discrimination and, consequently, ensuring true equality in society.

Multiple discrimination is one of the forms of discrimination that is insufficiently discussed, and it refers to the different treatment of a person or persons on several grounds. The concept of multiple discrimination is very complex and consists of multiple layers. This is precisely why it is the focus of this paper. The results of the research are preceded by an overview of the legal interpretation of the concept of discrimination and multiple (intersectional) discrimination and an analysis of the grounds and areas of discrimination arising from the most relevant international treaties prohibiting discrimination as well as the Anti-Discrimination Act that entered into force in 2009. The results of a survey conducted in April and May 2020 on more than 700 adult respondents focused on the most common grounds and areas of discrimination and more serious forms of discrimination in Croatia. The research covers more serious forms of discrimination as defined by the Anti-Discrimination Act, multiple discrimination, repeated discrimination, and continued discrimination. The research aimed to determine the most common grounds of discrimination and the areas in which discrimination most often occurs as well as the presence of more serious forms of discrimination in Croatia. It can be assumed that sex is the dominant ground of discrimination and that discrimination is most prevalent in the area of work and working conditions. It is assumed that multiple discrimination is present to a large extent in society.

\section{THE GROUNDS AND AREAS OF DISCRIMINATION}

Discrimination is any different treatment of person or persons on the grounds of sex, age, race, ethnic or national affiliation, religion, sexual orientation or any other legally protected grounds. ${ }^{1}$ Various international legal documents define discrimination differently, and many documents regulating the issue of discrimination do not provide a definition of the term. The definition of discrimination in the legal sciences differs from the definition of discrimination in other areas, and it also differs in the national legislation of states. That fact is the reason for the lack of a single definition of discrimination. ${ }^{2}$ Irrespective of differences in race, color, sex, language, religion, political or other opinion, national or social origin, property, birth or other status, the rights described in the United Nations Universal Declaration of Human Rights ${ }^{3}$

1 Sanja Vasiljević and Mario Vinković, Temeljna prava $i$ zabrana diskriminacije u praksi europskih i nacionalnih sudova (Zagreb: Narodne novine, 2019), 50.

2 Sanja Vasiljević, Slično i različito - diskriminacija u Europskoj uniji i Republici Hrvatskoj (Zagreb: Tim press, 2011), 26. See also Wouter Vandenhole, Non-discrimination and equality in the view of the UN human rights treaty bodies (Oxford: Intersentia, 2005), 33.

3 Universal Declaration of Human Rights, A/RES/217 A (III) of 10 December 1948. See also 
are guaranteed (Article 2). The non-discrimination, in particular on the grounds of race, color, sex, language, religion, political or other opinion, national or social origin, property, birth or any other circumstance, is ensured by the International Covenant on Civil and Political Rights, ${ }^{4}$ as well as equality before the law. The International Covenant on Economic, Social and Cultural Rights ${ }^{5}$ guarantees non-discrimination based on race, color, sex, language, political or any other opinion, national or social origin, property status, birth or any other circumstance. The definition of discrimination, namely racial discrimination, is adopted by the Convention on the Elimination of All Forms of Racial Discrimination of the United Nations. Racial discrimination $^{6}$ is defined any distinction, exclusion, restriction or preference based on race, color, descent, or national or ethnic origin which has the purpose or effect of nullifying or impairing the recognition, enjoyment or exercise, on an equal footing, of human rights and fundamental freedoms in the political, economic, social, cultural or any other field of public life (Article 1). Another document of the same organization, the Convention on the Elimination of All Forms of Discrimination against Women, defines discrimination against women ${ }^{7}$ as any distinction, exclusion or restriction made on the basis of sex which has the effect or purpose of impairing or nullifying the recognition, enjoyment or exercise by women, irrespective of their marital status, on a basis of equality of men and women, of human rights and fundamental freedoms in the political, economic, social, cultural, civil or any other field (Article 1). As the two conventions define discrimination on certain grounds, race and sex, the UN Human Rights Committee has taken the view that the notion of discrimination should be understood as any distinction, exclusion, restriction or preference which is based on any ground such as race, color, sex, language, religion, political or other opinion, national or social origin, property, birth or other status, and which has the purpose or effect of nullifying or impairing the recognition, enjoyment or exercise by all persons, on an equal footing, of all rights and freedoms. ${ }^{8}$

The Council of Europe Convention for the Protection of Human Rights and

Guðmundur S. Alfredsson and Asbjørn Eide (ed.), The Universal Declaration of Human Rights: a common standard of achievement (Boston: Martinus Nijhoff Publishers, 1999), 78.

4 International Covenant on Civil and Political Rights, A/RES/2200 A (XXI) of 16 December 1966.

5 International Covenant on Economic, Social and Cultural Rights, A/RES/2200 A (XXI) of 16 December 1966.

6 International Convention on the Elimination of All Forms of Racial Discrimination, A/ RES/2106 (XX) of 21 December 1965. See also Vandenhole, Non-discrimination and equality in the view of the UN human rights treaty bodies, 6-12 and Theodor Meron, "The meaning and reach of the international convention on the elimination of all forms of racial discrimination", American Journal of International Law 79, № 2 (1985): 286-288.

7 Convention on the Elimination of All Forms of Discrimination against Women, A/RES/34/180 of 18 December 1979. See also Marshall A. Freeman et al. (ed.), The UN Convention on the Elimination of all Forms of Discrimination Against Women: A commentary (Oxford: Oxford University Press, 2012), 57.

8 Human Rights Committee, General comment No 18: Non-discrimination, HRI/GEN/1/Rev.7, 1989. See also Vandenhole, Non-discrimination and equality in the view of the UN human rights treaty bodies, 43-44. 
Fundamental Freedoms ${ }^{9}$ does not provide a definition of discrimination either, but prohibits it on grounds such as sex, race, color, language, religion, political or other opinion, national or social origin, association with a national minority, property, birth or other circumstances (Article 14). The European Social Charter ${ }^{10}$ guarantees the enjoyment of all recognized rights without any discrimination, and emphasizes in particular race, color, sex, language, religion, political or other opinion, nationality or social origin, health, national minority, birth or other status. The right to equal opportunities and equal treatment is guaranteed in terms of employment and profession without discrimination on the grounds of sex (Article 20), but the European Social Charter does not define the concept of discrimination either.

In defining and implementing its policies and activities, the European Union committed to combating discrimination ${ }^{11}$ the on grounds of sex, racial or ethnic origin, religion or belief, disability, age, or sexual orientation (Article 10). The Charter of Fundamental Rights of the European Union ${ }^{12}$ does not define discrimination, but sets out the grounds for prohibition of any discrimination based on any ground such as sex, race, color, ethnic or social origin, genetic features, language, religion or belief, political or any other opinion, membership of a national minority, property, birth, disability, age or sexual orientation (Article 21).

The Anti-Discrimination Act $^{13}$ defines discrimination as placing at a disadvantage any person on the grounds of race or ethnicity or color, sex, language, religion, political or other belief, national or social origin, property status, trade union membership, education, social position, marital or family status, age, health condition, disability, genetic inheritance, gender identity, expression or sexual orientation, as well as persons related to him or her by kinship or other ties as well as on the basis of a misconception of grounds for discrimination (Article 1). Discrimination includes those characteristics, i.e. those bases that distinguish people from each other. These bases can be permanent, i.e. innate such as sex or race, and changeable or acquired, such as political or other beliefs or property status, and non-visible such as sexual orientation, whose possible visibility depends exclusively on the individual. ${ }^{14}$ The AntiDiscrimination Act applies to the actions of all state bodies, local and regional selfgovernment bodies as well as to the actions of legal entities with public authority and all legal and natural persons, especially in the areas of work and working conditions, which includes the possibility of independent and non-independent business and selection criteria and conditions for employment and promotion, as well as access

9 Convention for the Protection of Human Rights and Fundamental Freedoms, Croatian translation published in: Official Gazette № 18/1997, 6/1999, 14/2002, 13/2003, 9/2005, 1/2006, 2/2010.

10 European Social Charter, Croatian translation published in Official Gazette № 15/2002.

11 Treaty of Lisbon amending the Treaty on European Union and the Treaty establishing the European Community, signed at Lisbon, OJ C 306, 17 December 2007.

12 Charter of Fundamental Rights of the European Union, OJ C 303/1, 12 December 2007. See also Angela Ward, "The Impact of the EU Charter of Fundamental Rights on Anti-Discrimination Law: More a Whimper than a Bang?", Cambridge Yearbook of European Legal Studies, 20 (2018): 35-53.

13 The Anti-Discrimination Act (Zakon o suzbijanju diskriminacije), Official Gazette No 85/2008, $112 / 2012$.

14 Vasiljević, Slično i različito - diskriminacija u Europskoj uniji i Republici Hrvatskoj, 27-28. 
to all types of professional training and retraining; in the area of education, science and sports; social security, including social welfare, pension and health insurance and unemployment insurance; health care; judiciary and administration; housing; public information and media; access to and provision of goods and services; membership in trade unions, civil society organizations, political parties and other organizations, and participation in cultural and artistic creation (Article 8).

\section{SERIOUS FORMS OF DISCRIMINATION}

Multiple discrimination is a form of discrimination that is still not sufficiently recognized. This form of discrimination can have several grounds acting simultaneously, i.e. one or more grounds are intertwined and completely inseparable. ${ }^{15}$ A black woman or woman of a certain ethnic minority who is also a person with a disability may be a victim of discrimination on several legally protected grounds. ${ }^{16}$ The various grounds of discrimination have been observed individually, and over time it was accepted that discrimination could be committed on multiple grounds. However, there are different concepts that seek to clarify the issue of multiple discrimination and understanding. Multiple discrimination is recognized in the field of human rights, but scientific literature predominantly uses the concept of intersectional discrimination. ${ }^{17}$

The concept of intersectional discrimination was first used by Kimberlé Crenshaw in her analysis of the experiences of African American women members of the feminist movement in the United States that were not comparable to the experiences of white women members of the feminist movement or the experiences of African American people related to racial discrimination. Thus, the criticism targeted feminist politics that excludes race and antiracist politics that excludes sex. ${ }^{18}$ The concept of multiple discrimination refers to discrimination that affects the victim on different grounds, but at different times, or to the "cumulation of different discriminatory practices", while the concept of intersectional discrimination refers to discrimination that results from overlapping of different grounds. ${ }^{19}$

In 2000, The United Nations Human Rights Committee in General Interpretation $\mathrm{n}^{\circ} 28$ recognized that discrimination against women is often intertwined with discrimination on other grounds such as race, color, language, religion, political or

15 Vasiljević and Vinković, Temeljna prava $i$ zabrana diskriminacije u praksi europskih $i$ nacionalnih sudova, 59.

16 Paola Uccellari, "Multiple discrimination: How law can reflect reality", The equal rights review, 1 (2008): 24

17 Vasiljević, Slično i različito - diskriminacija u Europskoj uniji i Republici Hrvatskoj, 28-29.

18 Kimberlé Crenshaw, "Demarginalizing the intersection of race and sex: A Black feminist critique of antidiscrimination doctrine, feminist theory and antiracist politics", University of Chicago Legal Forum 140 (1989): 140. See also Mieke Verloo, "Multiple inequalities, intersectionality and the European Union", European Journal of Women's Studies 13, № 3 (2006): 212-214.

19 Vasiljević, Slično i različito - diskriminacija u Europskoj uniji i Republici Hrvatskoj, 29-30. See also Uccellari, "Multiple discrimination: How law can reflect reality": 25-26 and Timo Makkonen, Multiple, Compound and Intersectional Discrimination: Bringing the Experiences of the Most Marginalized to the Fore (Helsinki: Institute for Human Rights, Åbo Akademi Universit, 2002), 10-12. 
other opinion, national or social origin, property status, birth or other status, and that the Member States should indicate how discrimination on some other basis affects women, which includes information on measures taken to combat these effects. ${ }^{20}$ Still, the Interpretation does not offer a definition of multiple discrimination. The Declaration of the World Conference against Racism, Racial Discrimination, Xenophobia and Related Intolerance held in Durban in 2001 reaffirmed that the Member States should take sex into account in the protection and promotion of human rights and consequently recognize the multiple discrimination that women may face. In other words, Member States have recognized that victims of racial discrimination may also be victims of several other grounds of discrimination such as sex, language, religion, political or other opinion, social origin, property or other grounds. ${ }^{21}$ In 2016, the UN Human Rights Council accentuated the importance of the Durban Declaration by adopting a Resolution on the impact of multiple and intersectional discrimination and violence in the context of racism, racial discrimination, xenophobia and related intolerance of the full enjoyment of all human rights by women and girls with the aim of integrating gender perspectives into relevant policies and programs aimed at combating racial discrimination..$^{22}$

Council Directive 2000/43/EC on the implementation of the principle of equal treatment of persons irrespective of racial or ethnic origin prohibits multiple discrimination and recognizes women as frequent victims of multiple discrimination, but it does not define multiple discrimination. ${ }^{23}$ Women are also recognized as victims of discrimination by Council Directive 2000/78/EC which establishes a general framework for equal treatment in employment and occupation, but it does not provide a definition of multiple discrimination either. ${ }^{24}$ However, both Directive 2000/43/EC (Article 5) and Directive 2000/78/EC (Article 7) state the possibility of maintaining or adopting specific measures to prevent or compensate for disadvantages linked to racial or ethnic origin, i.e. to achieve the principle of equal treatment in relation to employment and occupation. The European Parliament has recognized the existence of multiple discrimination in Decision 771/2006/EC ${ }^{25}$ establishing the

20 Human Rights Committee, General Comment No 28, The equality of rights between men and women (article 3), CCPR/C/21/Rev.1/Add.10, 2000. See also Vasiljević, Slično i različito diskriminacija u Europskoj uniji i Republici Hrvatskoj, 83-88.

21 Report of the World Conference against Racism, Racial Discrimination, Xenophobia and Related Intolerance, Declaration, Durban, 31 August - 8 September 2001, A/CONF.189/12. See also Corine Lennox, "Reviewing Durban: Examining the Outputs and Review of the 2001 World Conference against Racism", Netherlands Quarterly of Human Rights 27, № 2 (2009): 192-220.

22 Addressing the impact of multiple and intersecting forms of discrimination and violence in the context of racism, racial discrimination, xenophobia and related intolerance on the full enjoyment of all human rights by women and girls, Resolution adopted by the Human Rights Council on 1 July 2016, A/HRC/RES/32/17.

23 Council Directive 2000/43/EC of 29 June 2000 implementing the principle of equal treatment between persons irrespective of racial or ethnic origin, OJ L 180, 19 July 2000.

24 Council Directive 2000/78/EC of 27 November 2000 establishing a general framework for equal treatment in employment and occupation, OJ L 303, 2 December 2000.

25 Decision No 771/2006/EC of the European Parliament and of the Council of 17 May 2006 
European Year of Equal Opportunities for All, where one of the objectives is to raise awareness of the right to equality regardless of sex, race, ethnic origin, religion or belief, disability, gender or sexual orientation, i.e. raising awareness of the problem of multiple discrimination. The European Union Agency for Fundamental Rights has recognized multiple discrimination as a phenomenon that manifests itself in two ways, as additional discrimination when a person is discriminated against on different grounds in separate situations or different areas and as intersectional discrimination when two or more grounds of discrimination act simultaneously, i.e. when it is not possible to separate them. ${ }^{26}$ The European Commission has adhered to the definition of multiple discrimination that states it is a situation in which discrimination takes place on several grounds. In addition to multiple discrimination, the Commission also emphasizes complex and intersectional discrimination. The former refers to a situation in which a person is discriminated against on the basis of two or more grounds of discrimination at the same time and where one basis binds to another, i.e. where one basis coincides with another or more of them. The latter refers to a situation in which multiple bases intertwine with each other and it is not possible to separate them. ${ }^{27}$

The Anti-Discrimination $\mathrm{Act}^{28}$ singles out multiple discrimination or discrimination committed against a certain person on more than one of the legally protected grounds as a more serious form of discrimination. In addition to multiple discrimination, as a more serious form of discrimination, the Act singles out repeated discrimination or discrimination committed several times and continued discrimination, i.e. discrimination which lasted a longer period of time (Article 6).

\section{RESEARCH OF THE GROUNDS AND SERIOUS FORMS OF DISCRIMINATION IN CROATIA}

One of the goals of the survey, which was conducted on a representative sample of 821 respondents with an error rate of $+/-4.61 \%$ and a security level of $99 \%$, was to determine the most common grounds and areas of discrimination in Croatia and the prevalence of more serious forms of discrimination. The total population of Croatia is 3,681,175 adult citizens..$^{29}$ The survey was conducted from April 28 to May 12, 2020 via communication platforms of human rights protection NGOs in Croatia

establishing the European Year of Equal Opportunities for All (2007) — towards a just society (Text with EEA relevance) OJ L 146, 31 May 2006.

26 Inequalities and multiple discrimination in access to and quality of healthcare, European Union Agency for Fundamental Rights, Publications Office of the European Union, Luxembourg, 2013, 13 .

27 Tackling Multiple Discrimination Practices, policies and laws, European Commission Directorate-General for Employment, Social Affairs and Equal Opportunities, Office for Official Publications of the European Communities, Luxembourg, 2007, 16-17.

28 The Anti-Discrimination Act (Zakon o suzbijanju diskriminacije), Official Gazette № 85/2008, $112 / 2012$.

29 Census of Population, Households and Dwellings 2011; Population by Sex and Age (Popis stanovništva, kućanstva i stanova 2011. Stanovništvo prema spolu i starosti), Bureau of Statistics, Zagreb, 2013. 
(Facebook, Twitter, WhatsApp, Snapchat, LinkedIn, Pinterest, Reddit, Tumblr, Skype, Viber and others as well as e-mails). The sample was stratified based on three sociodemographic indicators - sex, age, and level of education of respondents. There were a total of 761 complete answers included in the result processing. Incomplete answers are excluded from the processing. The survey included $60 \%$ of female and $40 \%$ of male respondents. Respondents were divided into four age groups - up to 30 years of age, 31 to 44, 45 to 60 and over 61 years of age. There were also four groups in relation to the level of education - primary school and lower, high school, college and university, and postgraduate studies.

Of the total number of respondents (761 people), $67.5 \%$ stated they are and probably were victims of discrimination, $21.7 \%$ stated they were not victims of discrimination, while $10.8 \%$ could not determine with certainty whether they were victims of discrimination (Fig. 1). Of the number of respondents who declare themselves as victims of discrimination (514 people), $60.3 \%$ claim to have been victims of multiple discrimination. Of the total number of respondents who cannot determine with full certainty whether they have been victims of discrimination ( 82 people), $53.7 \%$ are familiar with the grounds to which discrimination refers. In order to determine the most common grounds of discrimination, the further analysis included the responses of respondents who declared themselves to be victims of discrimination and those who cannot answer with certainty whether they were victims of discrimination but cite grounds of discrimination (558 people).

Figure 1 Cases of discrimination (\%)

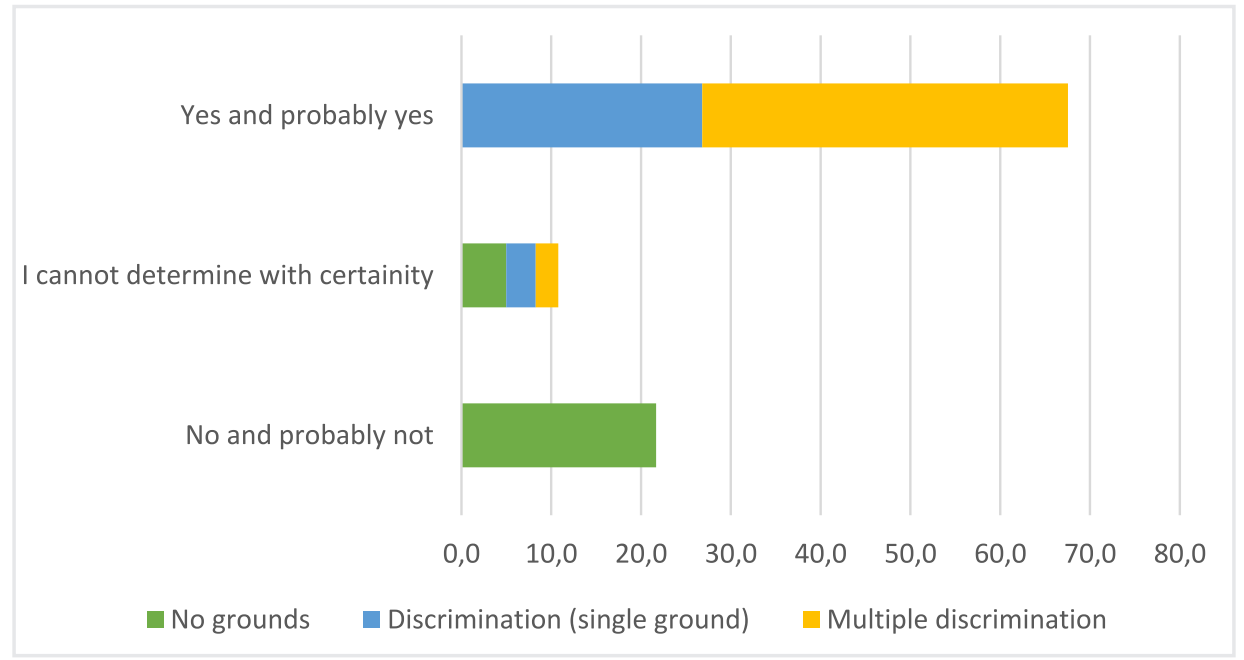

Source: Author.

Of the total number of respondents who state they were victims of discrimination (558 people), $41 \%$ claim to have been victims of discrimination on a single ground, while $59 \%$ claim to have been victims of multiple discrimination. The research used the term multiple instead of intersectional discrimination as a serious form 
of discrimination. This is primarily based on the definition of serious forms of discrimination as stated in the Anti-Discrimination Act. The second reason is the insufficient knowledge of the public on the term intersectional discrimination. The lack of familiarity with the concept of intersectional discrimination could have resulted in inaccurate feedback in the part of research related to serious forms of discrimination.

Of the total number of respondents who claim to have experienced singleground discrimination (229 people), the most common grounds are cited as follows: $27.7 \%$ political or other belief, followed by $23.4 \%$ sex, $12.8 \%$ social status, $7.7 \%$ education, and $7.2 \%$ ethnic and national affiliation (Fig. 2). Of the total number of respondents who claim to have been victims of multiple discrimination (329 people), the most common grounds for discrimination are cited as follows: $15.5 \%$ sex, $14.3 \%$ political or other belief, $11.6 \%$ age, $10.7 \%$ ethnic and national affiliation, and $8.1 \%$ education.

Figure 2 The most common grounds of discrimination (\%)

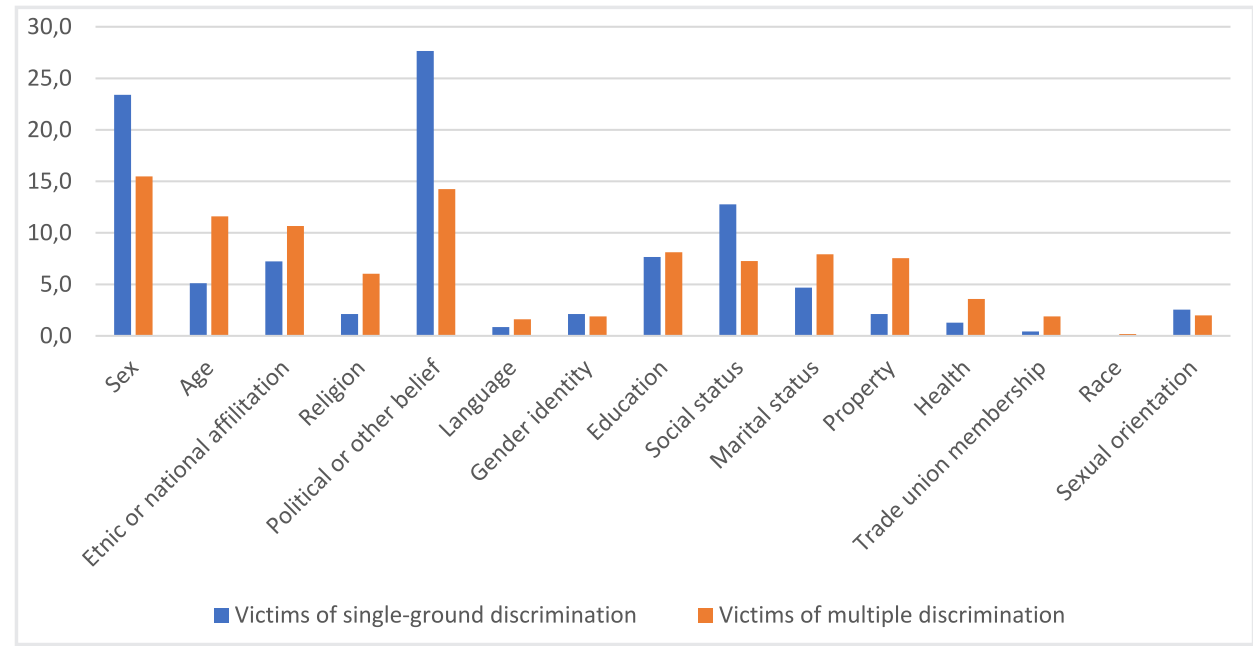

Source: Author.

In cases of multiple discrimination, on average (Fig. 3) sex and age are most commonly intertwined $(6.7 \%)$. In addition to age, sex intertwines with political or other belief (5.5\%), marital status (4.3\%), ethnic and national affiliation (4.3\%), education (3.7\%) and religion (3.4\%) as grounds in multiple discrimination. Political or other belief is most often simultaneous with ethnic and national affiliation (5.4\%), age $(4.8 \%)$, property $(3.4 \%)$, and social status (3.3\%). Ethnic and national affiliation is also intertwined with religion (3.9\%), while age is most commonly intertwined with education $(3.4 \%)$ and marital status (3.2\%). Social position is on average most often intertwined with property $(3.4 \%)$. 
Figure 3 The grounds of discrimination in cases of multiple discrimination (\%)

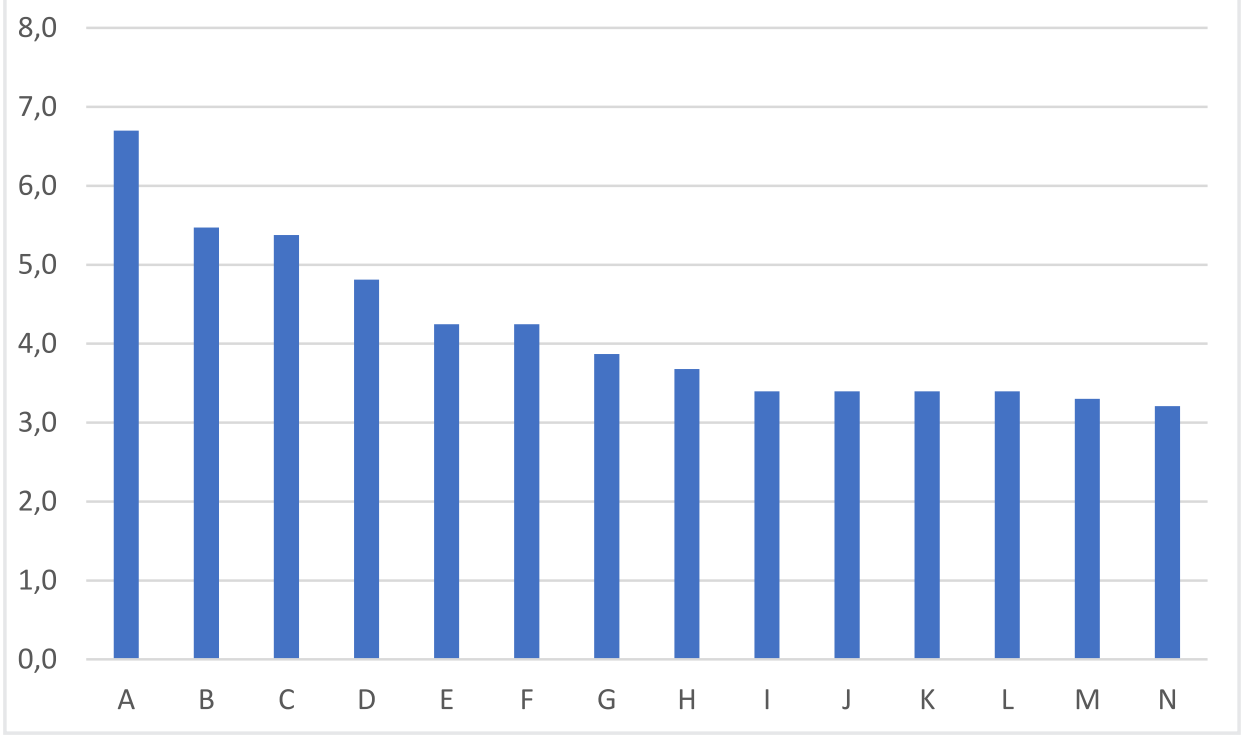

$A$-Sex and age; $B$-Sex and political or other belief; $C$-Political or other belief and ethnic or national affiliation; $D$ - Political or other belief and age; $E$-Sex and marital status; $F$-Sex and ethnic and national affiliation; $G-$ Ethnic or national affiliation and religion; $H-S e x$ and education; I-Age and education; $J$-Sex and religion; $K$ - Social status and property; $L$ - Political or other belief and property; $M$-Political or other belief and social status; $N$-Age and marital status.

\section{Source: Author.}

Of the total number of respondents who claim to have experienced singleground discrimination (229 people), $70.3 \%$ of them cite the area of work and working conditions as the most common area of discrimination (Fig. 4). Similarly, of the total number of respondents who claim to have been victims of multiple discrimination (329 people), the area of work and working conditions is the most cited area in which they experienced discrimination, i.e. in $30.1 \%$ of the cases. Other than the area of work and working conditions, victims of a single-ground discrimination most often cite the field of education (10.4\%) and membership in trade unions, civil society organizations, political parties and other organizations $(5.9 \%)$, while victims of multiple discrimination cite the area of education $(10.7 \%)$, the justice system $(10.5$ $\%)$, social security $(9 \%)$, access to goods and services $(8.4 \%)$, and healthcare $(7.6$ $\%)$.

The chi-square test, with $95 \%$ certainty, found that there are statistically significant differences in the grounds of discrimination between females and males who claim to have been victims of discrimination in the area of work and working conditions. Women are discriminated against on the grounds of sex and marital status more often than expected, but less than expected on the grounds of ethnic and nationality affiliation, political opinion, and social status. Men are discriminated against on the grounds of ethnicity and nationality, political or other belief and social 
status more often than expected, and less than expected on the grounds of sex and marital status. The difference was also found in relation to education, depending on the level of education. Respondents who completed secondary education are less discriminated against on the grounds of sex and more than expected because of education. Respondents with college and university degree are discriminated against on the grounds of marital status and sex more than expected, but less than expected in relation to education. And in the area of education, with $95 \%$ certainty, there is a statistically significant difference in the grounds of discrimination between females and males who declare themselves as victims of discrimination. In other words, women are more discriminated on the grounds of sex than expected, while men are less discriminated on the grounds of sex than expected.

In the area of justice system, the chi-square test determined with $95 \%$ certainty that there is a statistically significant difference in the grounds of discrimination between female and male victims of discrimination. Women are more than expected discriminated against on the grounds of sex in the judiciary system, while men are less than expected discriminated against on the grounds of sex.

Figure 4 The most common areas of discrimination (\%)

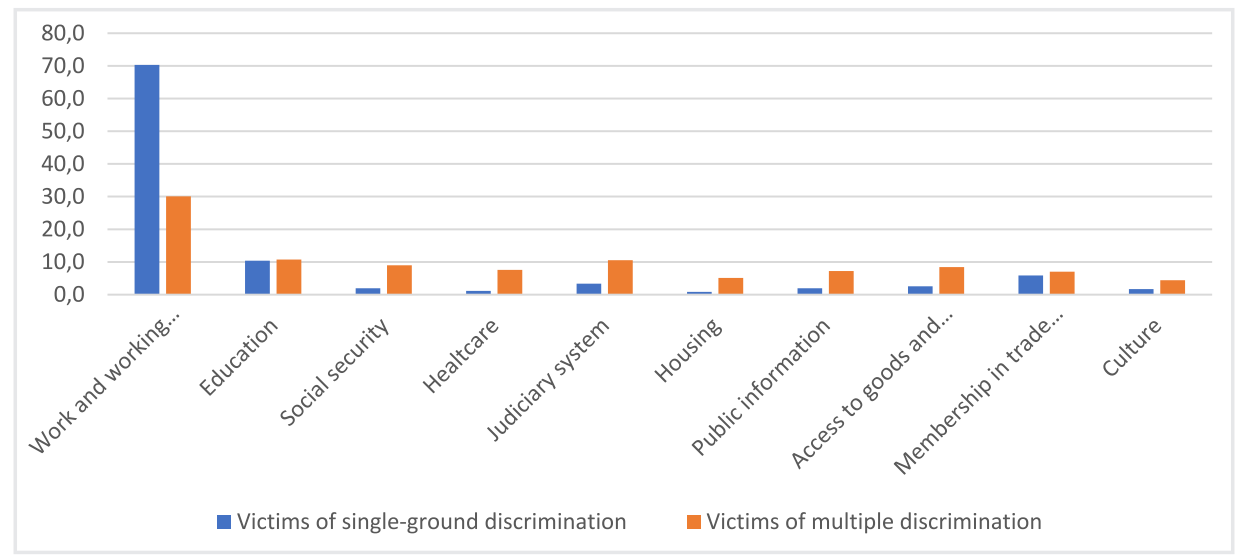

Source: Author.

Of the total number of respondents who declare themselves victims of discrimination (on a single ground), $57.2 \%$ are female. The analysis of the grounds of discrimination by sex indicates that women cite sex as the most common grounds of discrimination, $37.4 \%$ (Fig. 5), followed by political or other belief (20.6\%), social status $(9.2 \%)$, education $(6.9 \%)$, and marital status (6.1\%). Men cite political or other belief (37.8\%), social status (18.4\%), ethnic and nationality affiliation (12.2\%), and education $(9.2 \%)$ as the most common grounds of discrimination. 
Figure 5 Differences in discrimination based on the sex of respondents (\%)

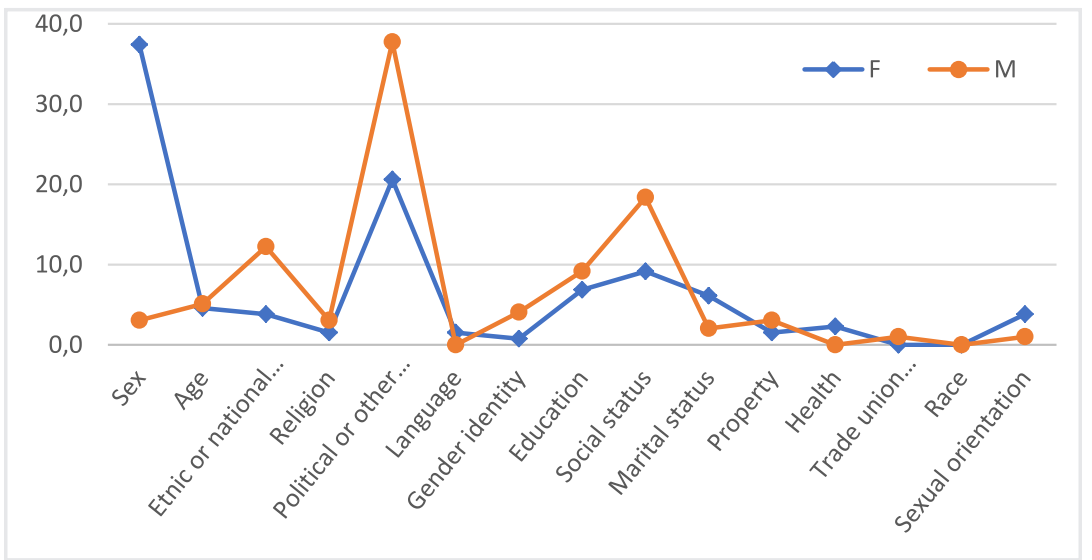

Source: Author.

Of the total number of respondents who state they are victims of multiple discrimination $66.3 \%$ are female. Women who state they are victims of multiple discrimination (Fig. 6) cite sec $(21.7 \%)$ as the most common basis of discrimination, followed by political and other belief $(12.3 \%)$, age $(12.1 \%)$, marital status $(9.6 \%)$ and ethnic and nationality affiliation (8.8\%). Male victims of multiple discrimination cite political or other belief (18.1\%), ethnicity and nationality affiliation (14.2\%), age $(10.6 \%)$, property $(10.3 \%)$, and social status $(9.5 \%)$ as the most common grounds of discrimination.

$(\%)$

Figure 6 Differences in multiple discrimination based on the sex of respondents

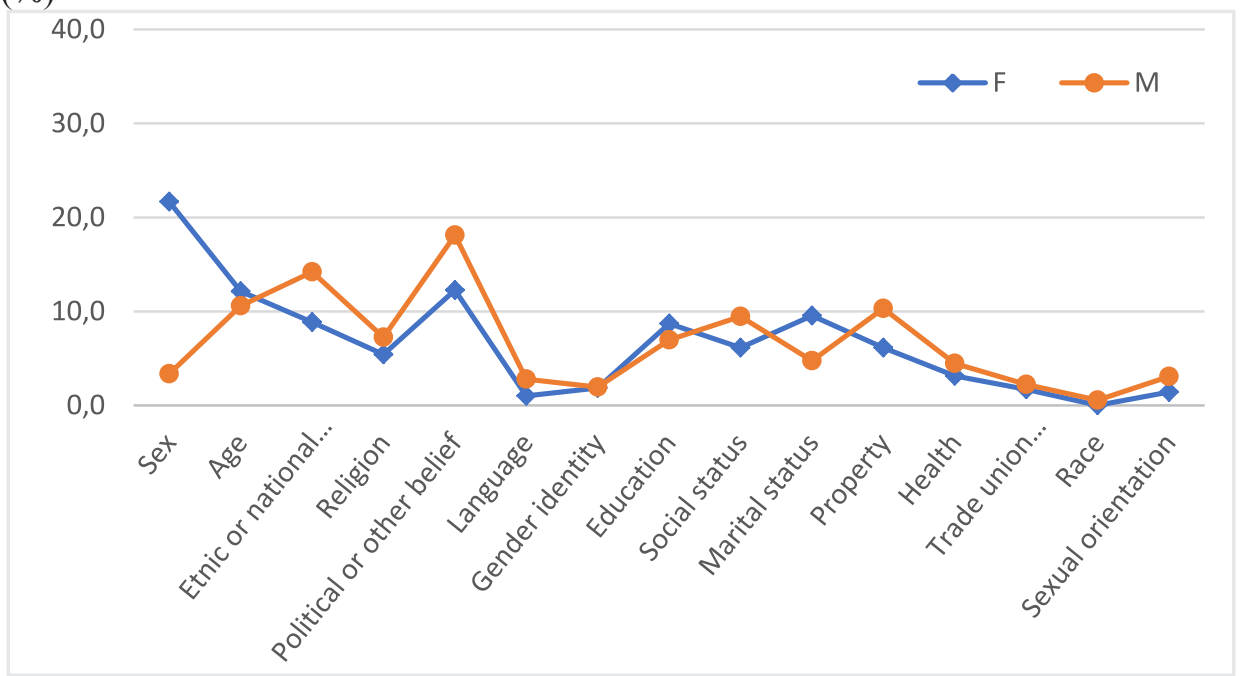

Source: Author. 
Respondents of up to 30 years of age (AG1) who are victims of single-ground discrimination (Fig. 7), cite sex (37.9\%), social status (13.8\%), and age and political or other belief $(10.3 \%)$ as the most common grounds of discrimination. Respondents in the age group of 31 to 44 (AG 2) cite political or other belief (32.7\%), followed by sex $(24.5 \%)$, social status $(11.2 \%)$, and education $(10.2 \%)$ as the most common grounds of discrimination. Respondents in the group of 45 to 60 (AG 3) cite political or other belief $(27.8 \%)$, sex $(19 \%)$, social status $(16.5 \%)$, and ethnic and nationality affiliation $(12.7 \%)$ as the most common grounds for discrimination. Lastly, respondents older than 61 years of age (AG 4) cite political or other belief (30.4 $\%$ ) as the most common basis for discrimination, followed by ethnic and nationality affiliation and education (13\%).

Figure 7 Differences in single-ground discrimination based on the age of respondents $(\%)$

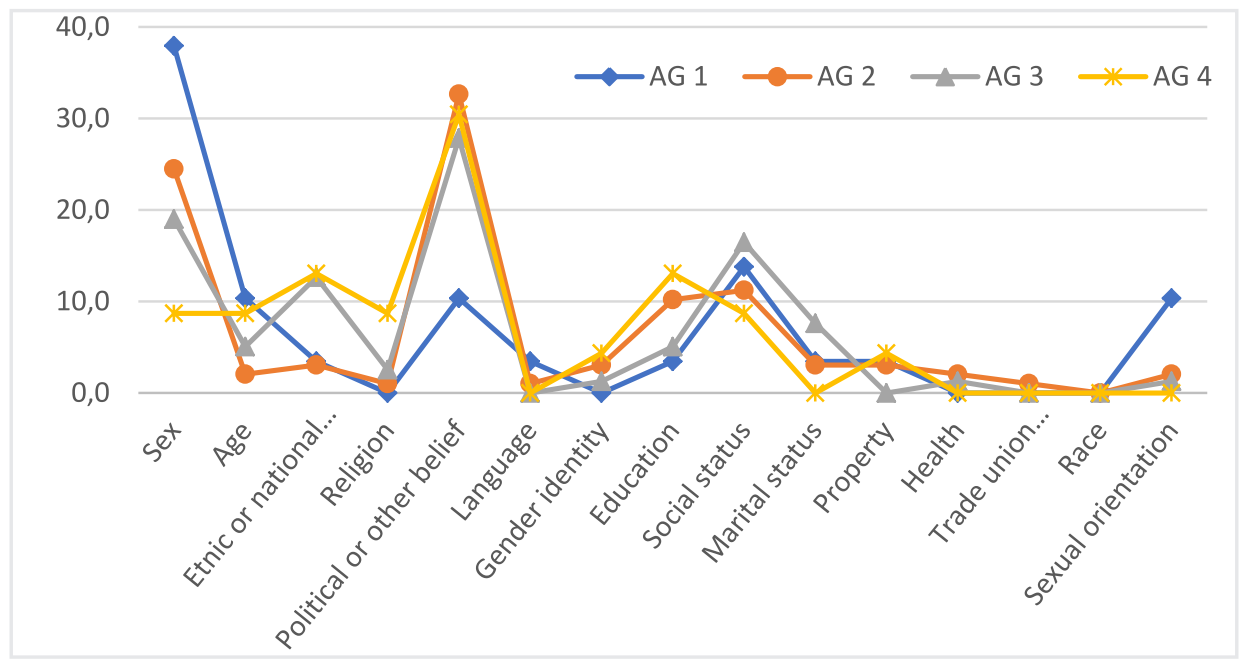

Source: Author.

Victims of multiple discrimination in the age group of up to 30 (Fig. 8) cite sex $(18.5 \%)$ and age $(13.4 \%)$ as the most common grounds of discrimination. Sex (16.2 $\%)$ is also the most common grounds of discrimination in the age group 31 to 44 , along with political and other belief $(13.6 \%)$ and age $(11.3 \%)$. Respondents in the age group 45 to 60 state political or other belief (16.9\%), ethnic and nationality affiliation, sex $(12.2 \%)$, and age $(11.3 \%)$ as the most common grounds of discrimination. Respondents older than 61 cite political or other belief $(25.5 \%)$, ethnicity and nationality affiliation, and sex (14.9\%), as well as social status $(12.8 \%)$ as the most common grounds of discrimination. 
Figure 8 Differences in multiple discrimination based on the age of respondents

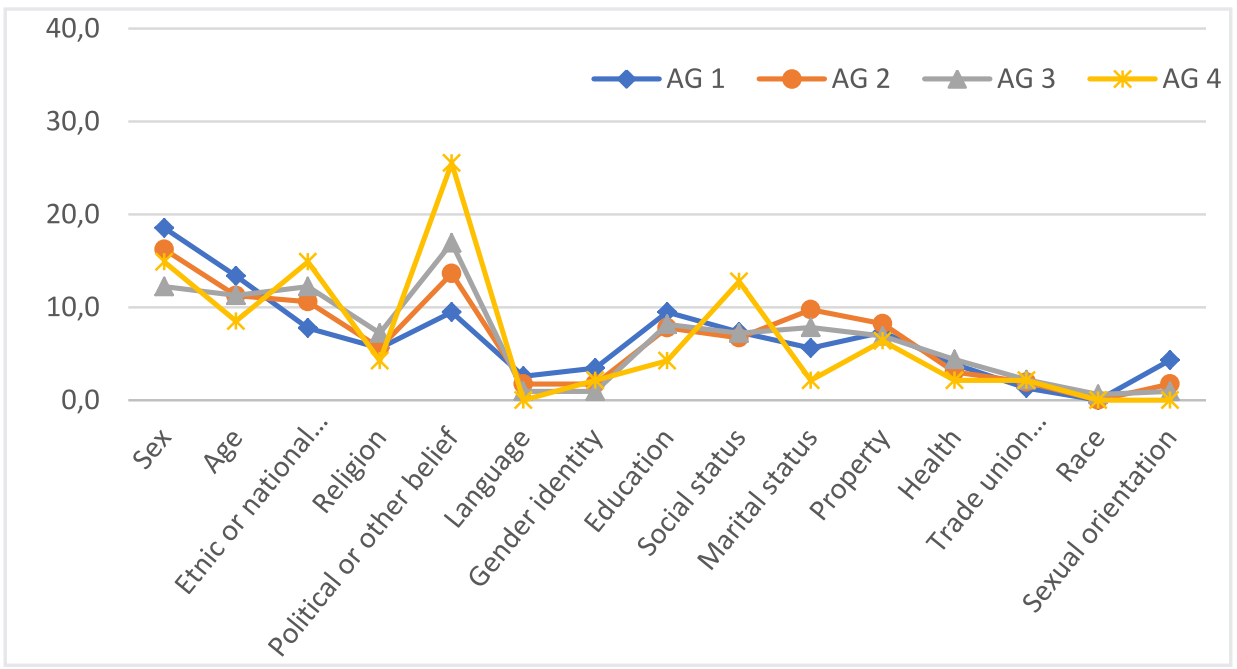

Source: Author.

Respondents who completed elementary school or are of lower education (LE 1) cite the following as the most common grounds of discrimination (Fig. 9): ethnicity and nationality affiliation, marital status, gender identity and political or other belief. Respondents who finished secondary education (LE 2) cite political or other belief (27.4\%), social status (17.9\%), and education (10.7\%) as the most common grounds of discrimination. Respondents with college and university degrees (LE 3) cite sex (33.3\%), political or other belief (26.8 \%), and social status (10.6\%) as the most common grounds of discrimination, while respondents who completed postgraduate studies (LE 4) cite political or other belief (38.9\%), sex (22.2\%), ethnic and nationality affiliation, and social status (11.1\%) as the most common grounds of discrimination. 
Figure 9 Differences in discrimination based on the level of education of respondents $(\%)$

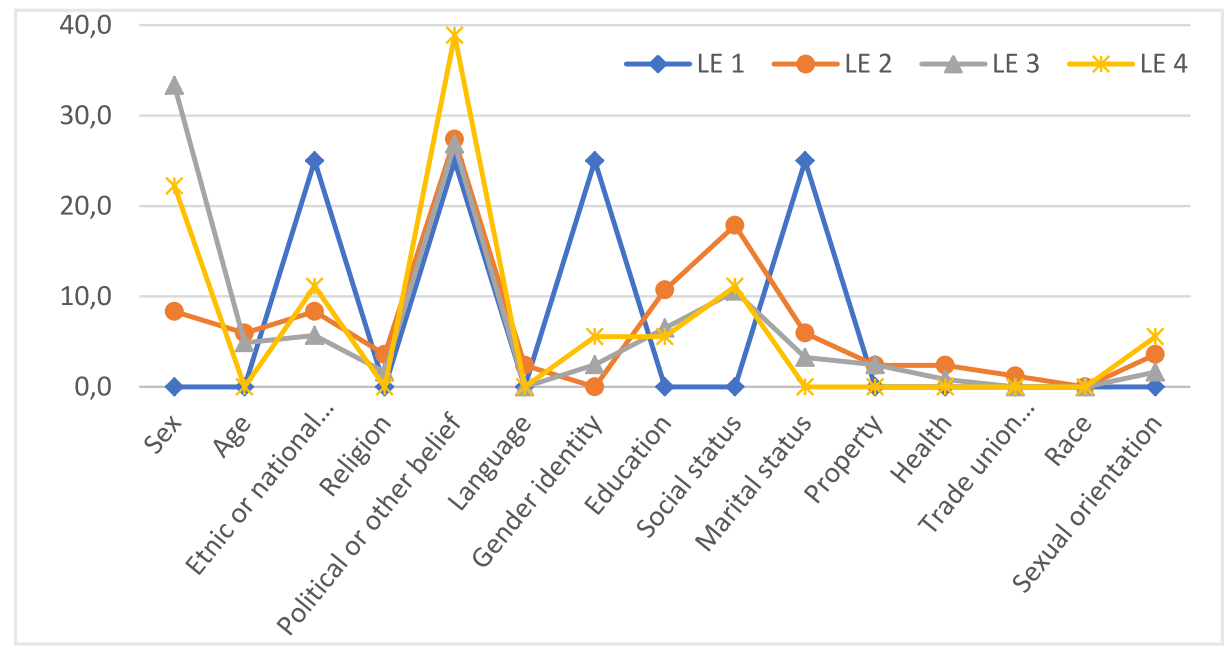

Source: Author.

Victims of multiple discrimination with the lowest level of education (Fig. 10) cite precisely education $(23.5 \%)$ as the most common grounds on which they are discriminated against, as well as sex, ethnic and nationality affiliation, marital status, political or other belief and health status (11.8\%). Sex and political or other belief $(12.3 \%)$ are cited as the most common grounds of multiple discrimination by respondents who completed secondary level of education, along with ethnic and nationality affiliation and age (11.6\%), followed closely by education $(11.4 \%)$. Respondents holding a college or university degree, who are victims of multiple discrimination, cite sex $(18.6 \%)$, along with political or other belief $(15 \%)$, age $(11.3$ $\%$ ), and marital status (10.9\%) as common grounds of discrimination. Respondents who completed postgraduate studies cite political or other belief $(17.9 \%)$, sex and age $(13.7 \%)$, and ethnic and nationality affiliation (12.8\%) as the most common grounds of multiple discrimination. 
Figure 10 Differences in multiple discrimination based on the level of education of respondents $(\%)$

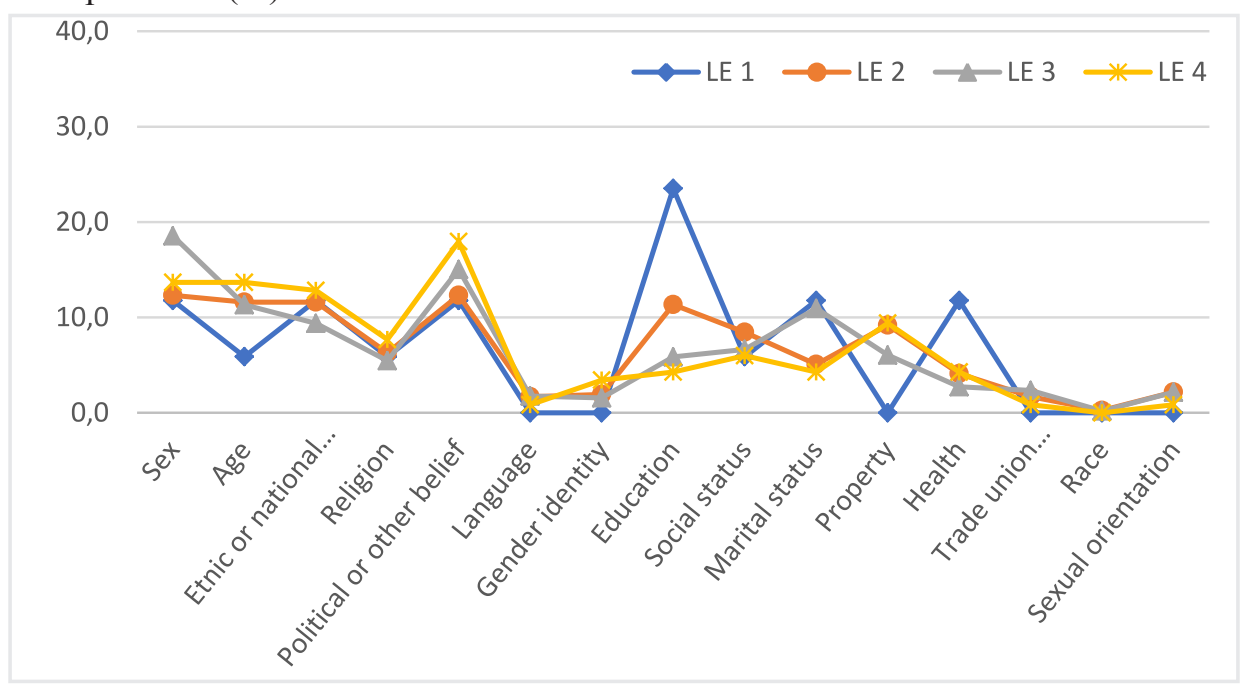

Source: Author.

Of the total number of respondents who declare themselves as victims of discrimination (558), 59\%(329) claim to have been victims of multiple discrimination. ${ }^{30}$ Moreover, $70.8 \%$ (395) of respondents claim to have been victims of repeated discrimination, and $12.2 \%$ (68) to have been victims of continued discrimination (Fig. 11). When it comes to repeated discrimination, it is important to note that 65 $\%$ (253) of respondents who state they have been victims of repeated discrimination also declare themselves as victims of multiple discrimination. Furthermore, $57.4 \%$ of respondents (39) who state they are victims of continued discrimination also declare themselves as victims of multiple discrimination. In other words, more than half of the respondents who are victims of repeated and continued discrimination are also victims of multiple discrimination. This means that, in addition to intertwined grounds of discrimination, there needs to be acknowledgment and discussion of intertwined serious forms of discrimination as well. 
Figure 11 Serious forms of discrimination

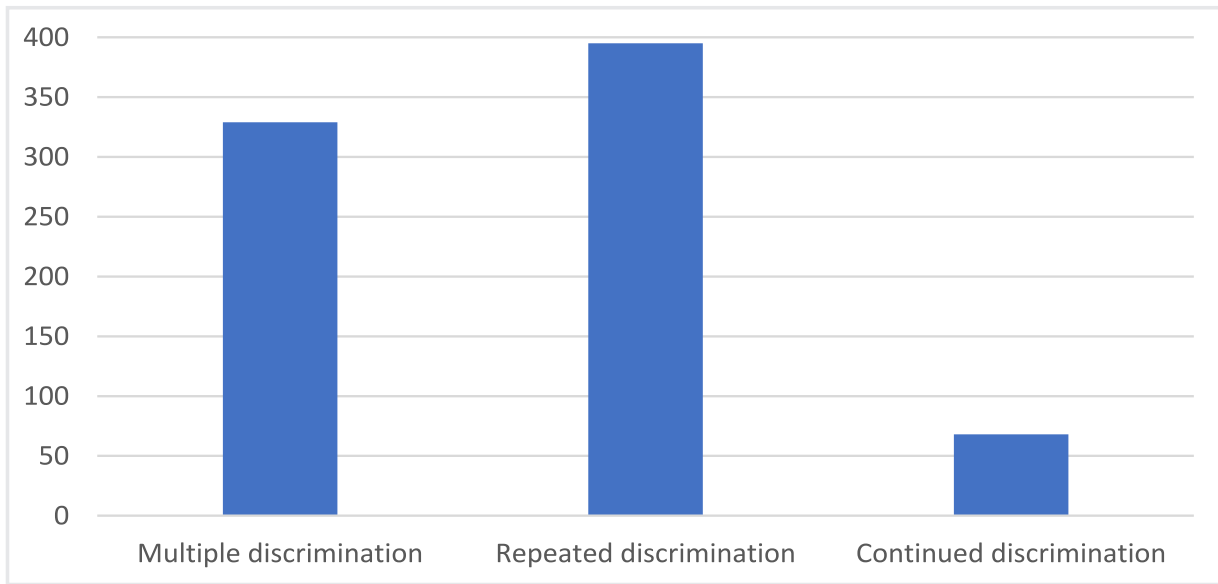

Source: Author.

Of the total number of respondents who state that they have been victims of repeated discrimination (395), $16.9 \%$ cite sex as the most common ground of discrimination, followed closely by political or other belief (16.2\%) (Fig. 12). Age is cited as the most common ground by $11.5 \%$ of victims of repeated discrimination, $10.6 \%$ cite ethnic and nationality affiliation, and $7 \%$ marital status. Although the number of respondents who state they have been victims of continued discrimination is significantly lower than the number of respondents who state they have been victims of repeated discrimination, $15.4 \%$ cite political or other belief as the most common ground of discrimination, followed by social status (13.8\%), sex (12\%), ethnic and nationality affiliation (12\%) and education $(10.7 \%)$.

Figure 12 Repeated and continued discrimination - common grounds of discrimination $(\%)$

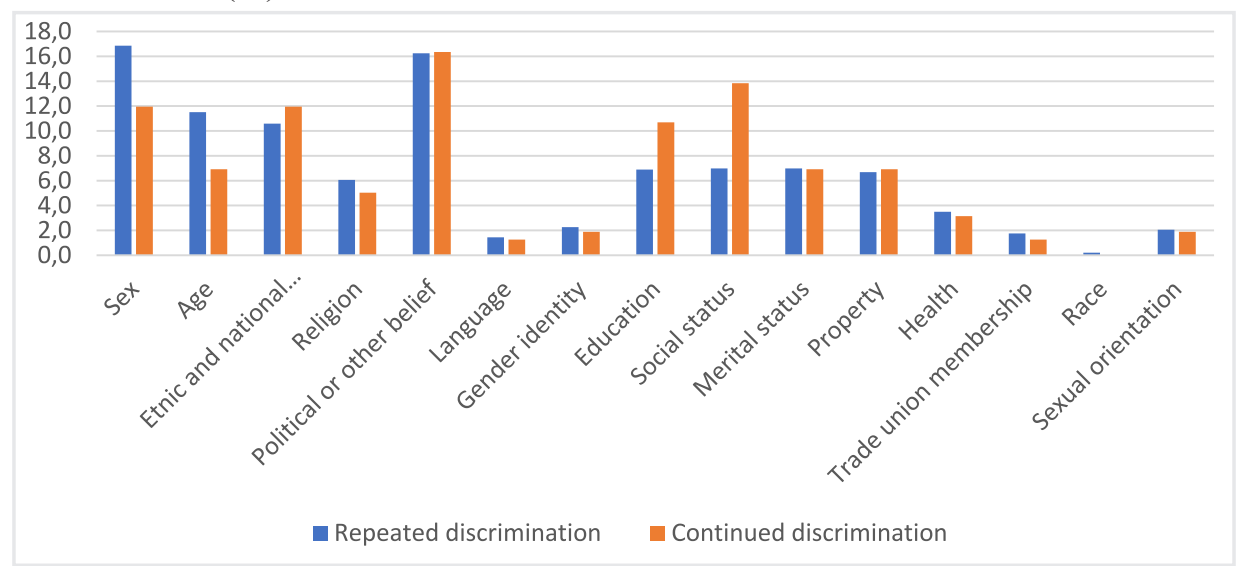

Source: Author. 
When it comes to areas of discrimination (Fig. 13), the majority of respondents who declare themselves as victims of repeated discrimination $(44.2 \%)$ as well as the majority of respondents who declare themselves as victims of continued discrimination $(50 \%)$ state they have experienced discrimination in the area of work and working conditions. Victims of repeated discrimination then cite the area of education (11.2 $\%)$, the judiciary system $(8 \%)$ and the area of access to goods and services (6.9 $\%)$. Victims of continued discrimination cite the areas of education, the judiciary system, and membership in trade unions, political parties, and other organizations approximately equally $(7.5 \%)$.

Figure 13 Repeated and continued discrimination - common areas of discrimination $(\%)$

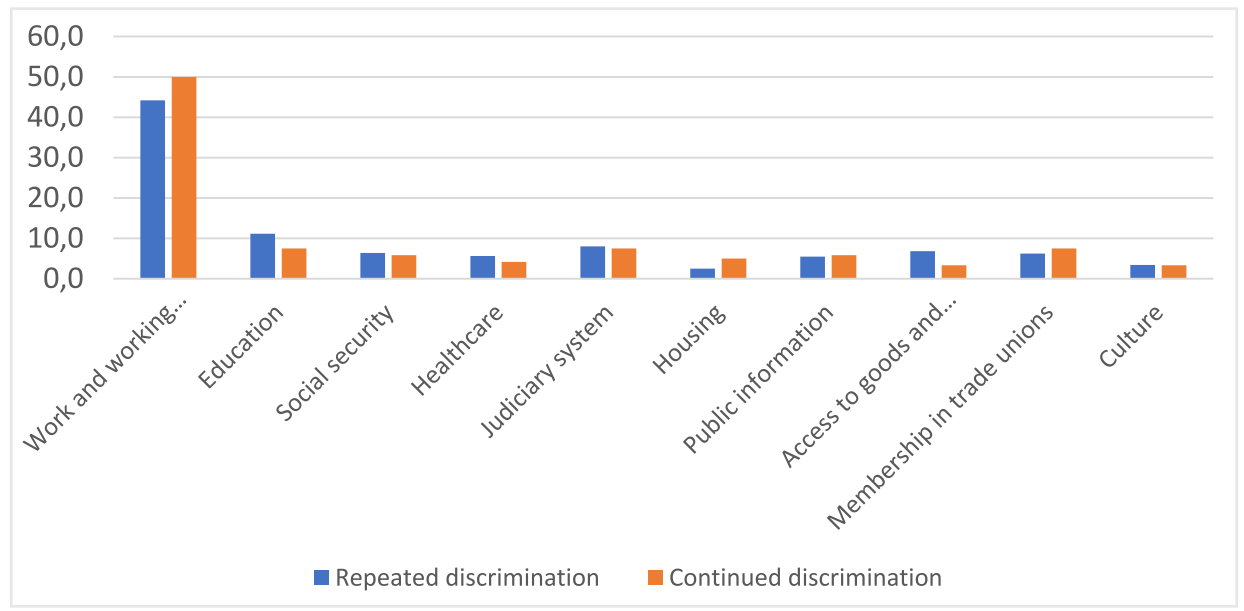

Source: Author.

If the issue of discrimination is perceived as one of the social problems, the number of victims of discrimination in Croatia, according to this research, leads to the conclusion that this issue is very high on the scale of social problems in Croatian society. More than $60 \%$ of respondents claim to have been in a situation where were treated differently on one, two or more grounds prohibited by law. Of the total number of discriminated people, almost $60 \%$ claim to have been discriminated against on two or more grounds, which show serious multiple layers of this problem. Political or other belief seems to be the dominant ground of discrimination, while in the case of multiple discrimination, the dominant basis is sex, i.e. on average, sex and age as the most commonly intertwined grounds. This is followed by sex and education, sex and ethnic and nationality affiliation, and sex and social status. Regardless of whether the discrimination respondents experienced is a single-ground or multiple, they cite the area of work and working conditions as the most common area of discrimination, and it is in the area of work that significant differences in the grounds of discrimination related to sex are noticeable. Women, who are predominantly affected by discrimination based on sex, are also affected by discrimination based on their marital status, which 
confirms the strong presence of the traditional understanding of the division of labor in Croatian society. This leads to the conclusion that marital status defines the position of women in the labor market, and consequently prevents women from selfactualizing at the same time in business and private or family life. In the area of work and working conditions, men are more affected by discrimination based on their ethnic or national affiliation and political or other belief than expected. The former is confirmed by the number of registered cases of discrimination in Croatia at the Office of the Ombudswoman. The latter could be explained by the difficulty in finding a job, which respondents often relate to political influences and power-ratio among political parties. With the increase of the level of education, the discrimination on the grounds of education lowers, i.e. respondents with a lower level of education are discriminated because of that more often than expected, while more educated respondents are less discriminated against on the grounds of education. In the area of education, women are discriminated against on the grounds of sex more than expected.

Age is often cited as one of the most common grounds of discrimination, predominantly by younger respondents, i.e. respondents younger than 30 , while political and other belief is cited by respondents aged 31 to 60, those who completed secondary education as well as those who completed postgraduate studies. Ethnic and nationality affiliation is cited as one of the most common grounds for discrimination by people of lower levels of education. The number of victims of ethnic discrimination increases with age. An additional burden for the forms of discrimination is certainly recurrence and duration. The number of respondents who cite these serious forms of discrimination in addition to multiple discrimination far exceeds the number of those who claim to have been victims of discrimination on a single basis and only once.

\section{CONCLUSION}

Although the legislative framework for protection against discrimination in Croatia defines more serious forms of discrimination, insufficient attention is paid to multiple, repeated, and continued discrimination. The issue of discrimination is by no means simple, and this research as well as previous research by the Office of the Ombudswoman, and records of reported cases of discrimination in Croatia, indicate that searching for causes and finding solutions requires an interdisciplinary approach. Part of the cause lies in traditional understandings of roles in society, stereotypes, and the lack of systematic education on the harmfulness of discrimination. On the other hand, one of the inputs to the solution need to be new anti-discrimination policies that do not ignore the intertwining and overlapping of different grounds of discrimination. This will guarantee better effectiveness of protection mechanisms. New anti-discrimination policies should pay special attention to more serious forms of discrimination affecting marginalized and vulnerable groups in society, such as national minorities. This will help them achieve equality and exercise all their rights, civil, economic, and social. The issue of education, i.e. the recognition of discrimination and especially more serious forms of it, remains a problem primarily due to the non-implementation of education for democratic citizenship, but also human rights within formal education. 
As observable in the results of this research, special attention needs to be paid to more serious forms of discrimination against women. Women make up almost 60 $\%$ of victims of single-ground discrimination, i.e. almost $70 \%$ of victims of multiple discrimination. As a dominant ground of discrimination against women, sex is also intertwined with women's political or other beliefs, marital status, social status and education, ethnic and nationality affiliation, and age. The latter is clearly visible in the youngest respondents, in the age group of up to 30. The fact that the area of work and working conditions is singled out as the dominant area of discrimination confirms there is a serious difference between formal and actual equality between women and men in this area. Only a well-designed anti-discrimination policy, which will take into account all social factors, i.e. the fact that a person belongs to different social groups, can reduce this gap and social exclusion. A mother of lower education in the labor market, who is also a member of a national minority could potentially be a victim of more serious forms of discrimination. The goal of a quality national anti-discrimination policy that takes all these grounds into account is to contribute to ensuring real equality of the citizens regardless of their permanent or acquired diversity.

\section{Books and articles}

\section{BIBLIOGRAPHY}

1. Alfredsson, Guðmundur S. and Eide, Asbjørn (ed.). The Universal Declaration of Human Rights: a common standard of achievement. Boston: Martinus Nijhoff Publishers, 1999.

2. Crenshaw, Kimberlé. "Demarginalizing the intersection of race and sex: A Black feminist critique of antidiscrimination doctrine, feminist theory and antiracist politics". University of Chicago Legal Forum 140 (1989): 139-167.

3. Freeman, Marshal A., Beate Rudolf, Christine Chinkin, Susann Kroworsch and Alison Sherrier (ed.). The UN Convention on the Elimination of All Forms of Discrimination against women: A commentary. Oxford: Oxford University Press, 2012.

4. Lennox, Corinne. "Reviewing Durban: Examining the Outputs and Review of the 2001

World Conference against Racism". Netherlands Quarterly of Human Rights 27, № 2 (2009): 191-235.

5. Makkonen, Timo. Multiple, Compound and Intersectional Discrimination: Bringing the Experiences of the Most Marginalized to the Fore. Helsinki: Institute for Human Rights, Åbo Akademi Universit, 2002.

6. Meron, Theodor. "The meaning and reach of the international convention on the elimination of all forms of racial discrimination". American Journal of International Law 79, No 2 (1985): 283-318.

7. Uccellari, Paola. "Multiple discrimination: How law can reflect reality". The equal rights review, $\mathrm{N}^{\circ} 1$ (2008): 24-49.

8. Vandenhole, Wouter. Non-discrimination and equality in the view of the UN human rights treaty bodies. Cambridge: Intersentia, 2005.

9. Vasiljević, Snježana. Slično i različito - diskriminacija u Europskoj uniji i Republici Hrvatskoj. Zagreb: Tim press, 2011.

10. Vasiljević, Snježana and Mario Vinković, Temeljna prava i zabrana diskriminacije $u$ praksi europskih i nacionalnih sudova. Zagreb: Narodne novine, 2019.

11. Verloo, Mieke. "Multiple inequalities, intersectionality and the European Union, European Journal of Women's Studies” 13, № 3 (2006): 211-228. 
12. Ward, Angela. The Impact of the EU Charter of Fundamental Rights on AntiDiscrimination Law: More a Whimper than a Bang?. Cambridge Yearbook of European Legal Studies 20 (2018): 32-60.

Legal sources

1. Addressing the impact of multiple and intersecting forms of discrimination and violence in the context of racism, racial discrimination, xenophobia and related intolerance on the full enjoyment of all human rights by women and girls, Resolution adopted by the Human Rights Council on 1 July 2016, A/HRC/RES/32/17.

2. Charter of Fundamental Rights of the European Union, OJ C 303/1, 12.12.2007.

3. Convention on the Elimination of All Forms of Discrimination against Women, A/ RES/34/180 of 18 December 1979.

4. Council Directive 2000/43/EC of 29 June 2000 implementing the principle of equal treatment between persons irrespective of racial or ethnic origin, OJ L 180, 19.7.2000.

5. Council Directive $2000 / 78 / \mathrm{EC}$ of 27 November 2000 establishing a general framework for equal treatment in employment and occupation, OJ L 303, 2.12.2000.

6. Decision No 771/2006/EC of the European Parliament and of the Council of 17 May 2006 establishing the European Year of Equal Opportunities for All (2007) — towards a just society (Text with EEA relevance), OJ L 146, 31.5.2006.

7. European Social Charter, Croatian translation published in Official Gazette $n^{\circ}$ 15/20002.

8. Human Rights Committee, General Comment № 18, Non-discrimination, HRI/GEN/1/ Rev.7, 1989.

9. Human Rights Committee, General Comment $N^{\circ} 28$, The equality of rights between men and women (article 3), CCPR/C/21/Rev.1/Add.10, 2000.

10. International Convention on the Elimination of All Forms of Racial Discrimination, A/ RES/2106 (XX) of 21 December 1965.

11. International Covenant on Civil and Political Rights, A/RES/2200 A (XXI) of 16 December 1966.

12. International Covenant on Economic, Social and Cultural Rights, A/RES/2200 A (XXI) of 16 December 1966.

13. Convention for the Protection of Human Rights and Fundamental Freedoms, Croatian translation published in: Official Gazette - MU 18/1997, 6/1999, 14/2002, 13/2003, 9/2005, 1/2006, 2/2010.

14. Report of the World Conference against Racism, Racial Discrimination, Xenophobia and Related Intolerance, Declaration, Durban, 31 August - 8 September 2001, A/CONF.189/12

15. Treaty of Lisbon amending the Treaty on European Union and the Treaty establishing the European Community, signed at Lisbon, OJ C 306, 17 December 2007.

16. Universal Declaration of Human Rights, A/RES/217 A (III) of 10 December 1948.

17. Anti-discrimination Act (Zakon o suzbijanju diskriminacije), Official Gazette $N^{\circ} 85 / 2008$, $112 / 2012$.

\section{Official publications}

1. Census of Population, Households and Dwellings 2011, Population by sex and age (Popis stanovništva, kućanstva i stanova 2011. Stanovništvo prema spolu i starosti.), Bureau of Statistics, Zagreb, 2013.

2. Inequalities and multiple discrimination in access to and quality of healthcare, European Union Agency for Fundamental Rights, Publications Office of the European Union, Luxembourg, 2013.

3. Tackling Multiple Discrimination Practices, policies and laws, European Commission Directorate-General for Employment, Social Affairs and Equal Opportunities, Office for Official Publications of the European Communities, Luxembourg, 2007. 


\section{Sanja Bježančević*}

Sažetak

\section{OSNOVE I TEŽI OBLICI DISKRIMINACIJE U HRVATSKOJ}

Iako zakonodavni okvir zaštite od diskriminacije u Hrvatskoj pokriva nezanemariv broj osnova te ga možemo nazvati zadovoljavajućim, diskriminacija u društvu prisutna je u većoj mjeri od one registrirane kroz pritužbe Uredu pučke pravobraniteljice. Različito postupanje prema osobi ili osobama može uključivati više različitih zakonom zaštićenih osnova što rezultira težim oblikom diskriminacije koji je prema Zakonu o suzbijanju diskriminacije definiran kao višestruka diskriminacija. Koncept višestruke diskriminacije vrlo je složen i slojevit i fokus je ovoga znanstvenog istraživanja provedenog na uzorku od 761 ispitanika koji je stratificiran po spolu ispitanika, njihovom obrazovanju i dobi. Hi-kvadrat testom ispitana je veza između osnova diskriminacije koje navode ispitanici koji se izjašnjavaju kao žrtve diskriminacije u području rada i radnih uvjeta, u području obrazovanja i pravosuđa te njihovog spola, razine obrazovanja i njihove dobi. Iz rezultata istraživanja je vidljivo da je više od polovice ispitanika doživjelo neki oblik diskriminacije te da je više od polovice ispitanika koji se izjašnjavaju kao žrtve diskriminacije doživjelo neki od težih oblika diskriminacije.

Ključne riječi: diskriminacija; osnove diskriminacije;područjadiskriminacije; višestruka diskriminacije; Europska unija.

* Sanja Bježančević, mag.oec., Poljoprivredni institut Osijek; sanja.bjezancevic@gmail.com; ORCID: https://orcid.org/0000-0002-5253-2581. 